\title{
Molecular epidemiology of infectious hematopoietic necrosis virus reveals complex virus traffic and evolution within southern Idaho aquaculture
}

\author{
Ryan M. Troyer ${ }^{1,2,3}$, Gael Kurath ${ }^{1,2, *}$ \\ ${ }^{1}$ Department of Pathobiology, University of Washington, Seattle, Washington 98195, USA \\ ${ }^{2}$ Western Fisheries Research Center, United States Geological Survey, Biological Resources Division, 6505 NE 65 th St., \\ Seattle, Washington 98115, USA \\ ${ }^{3}$ Present address: Division of Infectious Diseases, Case Western Reserve University, Cleveland, Ohio 44118, USA
}

\begin{abstract}
Infectious hematopoietic necrosis virus (IHNV) is a rhabdovirus which infects salmon and trout and may cause disease with up to $90 \%$ mortality. In the Hagerman Valley of Idaho, IHNV is endemic or epidemic among numerous fish farms and resource mitigation hatcheries. A previous study characterizing the genetic diversity among $84 \mathrm{IHNV}$ isolates at 4 virus-endemic rainbow trout farms indicated that multiple lineages of relatively high diversity co-circulated at these facilities (Troyer et al. $2000 \mathrm{~J}$ Gen Virol. 81:2823-2832). We tested the hypothesis that high IHNV genetic diversity and co-circulating lineages are present in aquaculture facilities throughout this region. In this study, 73 virus isolates from 14 rainbow trout farms and 3 state hatcheries in the Hagerman Valley, isolated between 1978 and 1999, were genetically characterized by sequence analysis of a 303 nucleotide region of the glycoprotein gene. Phylogenetic and epidemiological analyses showed that multiple IHNV lineages co-circulate in a complex pattern throughout private trout farms and state hatcheries in the valley. IHNV maintained within the valley appears to have evolved significantly over the 22 yr study period.
\end{abstract}

KEY WORDS: IHNV - Molecular epidemiology · Virus evolution · Fish virus · Idaho trout · Rhabdovirus

\section{INTRODUCTION}

Infectious hematopoietic necrosis virus (IHNV) is the type species of the genus Novirhabdovirus (Walker et al. 2000) and infects wild and cultured salmon and trout. The manifestation of disease resulting from infection with IHNV depends on many viral, host and environmental factors. Typically, infection of salmonid fry results in acute disease while infection of adults more frequently results in development of a chronic infection or possible carrier state (Wolf 1988, p. 83-114, Bootland \& Leong 1999). The virus is native to Pacific salmonid fishes and its current North American range mirrors that of Pacific salmonids, stretching from Alaska to northern Cali- fornia and inland to Idaho. IHNV is the most significant viral pathogen of salmon and trout in North America and thus the genetic diversity of IHNV is of interest for understanding the epidemiology and evolution of the virus. Previous studies have compared IHNV isolates in terms of biological differences such as cell culture plaque size, antigenic differences, electrophoretic mobility of viral proteins, T1 ribonuclease fingerprint patterns, and nucleotide sequencing of a limited number of isolates (Mulcahy et al. 1984, Hsu et al. 1986, Winton et al. 1988, Ristow \& Arnzen de Avila 1991, LaPatra et al. 1994, Nichol et al. 1995, Oshima et al. 1995, ). Our laboratory is currently analyzing the genetic diversity of IHNV throughout its geographic range using the ribonucle- 
ase (RNase) protection assay and direct nucleotide sequencing (Anderson et al. 2000, Emmenegger et al. 2000, Troyer et al. 2000, Emmenegger \& Kurath 2002, Kurath et al. 2003). Collectively, these studies support the hypothesis that IHNV strain-relatedness generally correlates with geography rather than host species or temporal factors.

The state of Idaho accounts for $75 \%$ of U.S. foodsize trout production ${ }^{1}$. The majority of this industry is located along a stretch of the Snake River in southcentral Idaho associated with an abundance of water flowing from the Eastern Snake River Aquifer through numerous natural springs. For the purposes of simplicity and clarity, this region of intensive Oncorhynchus mykiss (rainbow trout) aquaculture, encompassing the Twin Falls to Hagerman reach of the mid-Snake River from river mile 610 to river mile 569, is referred to in this study as the 'Hagerman Valley,' although it exceeds the technical boundaries of what is commonly known as the Hagerman Valley. Rainbow trout have been farmed continuously in this region since 1928, and the area also has federal and state hatcheries that primarily raise rainbow trout and steelhead trout (Brannon \& Klontz 1989). Currently there are 3 state fish hatcheries, 1 national fish hatchery, and approximately 100 trout farms of various sizes (G. Fornshell, University of Idaho Extension, pers. comm.). These facilities are served by a variety of water sources which include: first-use spring water piped directly to the facility, first-use spring water channeled via unprotected waterway, and surface water with previous uses (such as irrigation or fish culture). A year-round supply of $15^{\circ} \mathrm{C}$ spring water and photoperiod manipulation of rainbow trout broodstock allow fish to be produced year-round in the Hagerman Valley. Typically, rainbow trout are initially reared from IHNV-free eggs to the fry lifestage in enclosed buildings with protected water supplies and are subsequently moved into multiple outdoor rearing units or ponds to be reared to market size. Prior to 1977, fish culture facilities in the valley did not experience significant levels of disease associated with IHNV. However, acute IHN began to appear in the Hagerman Valley with 2 epidemics at independent sites in 1977 (Busch 1983). These outbreaks did not appear to be associated with marked changes in aquaculture practices, leading some to speculate that the manifestation of acute IHN at this time represented an adaptation of virus already present in the Hagerman Valley (Busch 1983). Alternatively, the appearance of acute IHN

${ }^{1}$ USDA Economic Research Service (2001). Aquaculture Outlook (March, 2001). available at: http://usda.mannlib.cornell.edu/reports/erssor/livestock/ldp-aqs/2001/ may have resulted from a new introduction of virus from an exogenous source. From 1978 through the early 1980s, IHN appeared progressively at additional facilities throughout the valley (Busch 1983). Since that time, the virus has been endemic in the valley, although some facilities do not experience disease and may be free of virus. IHN-associated mortality and deformities in surviving fish result in serious economic losses to the Idaho trout industry.

The first reports of IHNV diversity in the Hagerman Valley were serological studies conducted by LaPatra et al. $(1991,1994)$, who used a panel of monoclonal and polyclonal antibodies to distinguish 10 different virus neutralization profiles among 106 isolates from rainbow trout at 4 farms located along 12 river miles. Given this surprising level of antigenic heterogeneity, we subsequently chose to genetically characterize $84 \mathrm{IHNV}$ isolates from the same 4 trout farms over a period of 20 yr (Troyer et al. 2000). Among these 84 isolates, there were 46 unique glycoprotein gene RNase protection haplotypes, which revealed greater diversity than has been found among IHNV isolates from much larger geographic regions (Emmenegger et al. 2000, Emmenegger \& Kurath 2002, Kurath et al. 2003, Anderson et al. unpubl. data). Nucleotide sequence analyses of a 303 nucleotide (nt) region of the glycoprotein gene (mid$\mathrm{G}$ region) revealed up to $7.6 \%$ nucleotide divergence within isolates from this 4 farm study site. This is the highest level of diversity reported for IHNV to date. Phylogenetic analyses revealed 4 monophyletic subclades representing 4 virus lineages that were distributed among facilities, with each facility maintaining multiple lineages. These results suggested that co-circulating IHNV lineages of relatively high diversity are present among the 4 rainbow trout farms studied.

This data provided a detailed picture of IHNV diversity and evolution within 4 trout farms, all owned by the same producer. However, the Hagerman Valley region, as we have defined it, includes about 100 rainbow trout farms and additional state and federal resource mitigation hatcheries culturing both trout and anadromous salmonids. Thus, we sought to test the hypothesis that high IHNV genetic diversity and cocirculating lineages are characteristic of aquaculture facilities throughout the region. Since nucleotide sequence analyses of the mid-G region were highly informative in the original study (Troyer et al. 2000), we chose to use this technique to characterize 73 additional IHNV isolates: 59 isolates from 14 private trout farm facilities (not including the 4 farms previously studied) and 14 isolates from the 3 state hatcheries located in the Hagerman Valley (Table 1). These viruses were isolated between 1978 and 1999. 
Table 1. Infectious hematopoietic necrosis virus. IHNV isolates and their sites of isolation, dates of isolation (mo/d/yr), and subclade designations. Each isolate originated from a rainbow trout host unless otherwise indicated. (St: steelhead trout, Ct: cutthroat trout, Coho: coho salmon, R/St: rainbow trout $\times$ steelhead trout hybrid, R/Ct: rainbow trout $\times$ cutthroat trout hybrid.) Adult: mature rainbow trout adult. All other fish are fry, juvenile, or unknown lifestage. Sites 1-14 indicate private rainbow trout farm facilities 1-14; X, Y, and Z: Idaho state hatchery facilities; na: site of isolation is not known. Subclade designation was determined by phylogenetic analyses as described in 'Materials and methods' and Fig. 1

\begin{tabular}{|c|c|c|c|c|c|c|c|}
\hline Isolate & Site & Date & $\begin{array}{c}\text { Subclade } \\
\text { designation }\end{array}$ & Isolate & Site & Date & $\begin{array}{c}\text { Subclade } \\
\text { designation }\end{array}$ \\
\hline Hg001-88 (St) & $\mathrm{Y}$ & 07.13 .88 & $\mathrm{~N}$ & Hg141-94 & 9 & 05.26 .94 & $\mathrm{C}$ \\
\hline Hg002-88 (St) & $\mathrm{Z}$ & 03.22 .88 & B & Hg143-96 & 9 & 05.13 .96 & B \\
\hline Hg003-90 & $\mathrm{X}$ & 01.16 .90 & $\mathrm{E}$ & Hg144-96 & 1 & 09.16 .96 & $\mathrm{C}$ \\
\hline Hg004-90 (R/St) & $\mathrm{X}$ & 09.05 .90 & $\mathrm{C}$ & Hg146-97 & 7 & 04.07 .97 & B \\
\hline Hg005-91 (R/Ct) & $\mathrm{X}$ & 07.01 .91 & $\mathrm{E}$ & $\operatorname{Hg} 147-89$ & 1 & 04.11 .89 & $\mathrm{D}$ \\
\hline Hg006-91 (St) & $\mathrm{Z}$ & 07.10 .91 & $\mathrm{E}$ & Hg148-90 & 9 & 06.06 .90 & $\mathrm{C}$ \\
\hline Hg009-92 (St) & $\mathrm{Y}$ & 07.23 .92 & $\mathrm{C}$ & Hg149-90 & 2 & 10.02 .90 & $\mathrm{C}$ \\
\hline Hg010-92 & $\mathrm{X}$ & 07.28 .92 & $\mathrm{C}$ & Hg150-93 & 2 & 08.16 .93 & B \\
\hline Hg011-93 (Coho) & $\mathrm{X}$ & 04.09 .93 & B & Hg151-92 & 4 & 12.03 .92 & $\mathrm{C}$ \\
\hline Hg012-93 (St) & $\mathrm{Y}$ & 07.21 .93 & $\mathrm{C}$ & Hg152-96 & 9 & 07.15 .96 & $\mathrm{C}$ \\
\hline Hg016-98 & 12 & 09.29 .98 & $\mathrm{C}$ & Hg201-78 & 10 & 6/?/78 & $\mathrm{N}$ \\
\hline Hg017-98 & 12 & 10.15 .98 & B & Hg203-80 & na & $1 / ? / 80$ & $\mathrm{~N}$ \\
\hline Hg018-99 & 12 & 01.08 .99 & B & Hg204-81 & na & 3/?/81 & $\mathrm{N}$ \\
\hline Hg019-99 & 12 & 12.06 .99 & B & Hg205-83 & 7 & 01.05 .83 & $\mathrm{~F}$ \\
\hline Hg020-99 & 5 & 02.17 .99 & B & Hg206-83 & 7 & 01.05 .83 & $\mathrm{~F}$ \\
\hline Hg113-89 & 9 & 12.11 .89 & $\mathrm{C}$ & Hg207-83 & 7 & 01.05 .83 & $\mathrm{~F}$ \\
\hline Hg114-90 & 4 & 01.11 .90 & $\mathrm{D}$ & Hg209-83 & 7 & 01.05 .83 & $\mathrm{~N}$ \\
\hline Hg115-90 & 4 & 01.31 .90 & $\mathrm{D}$ & Hg210-83 & 12 & 01.13 .83 & $\mathrm{~N}$ \\
\hline Hg117-90 & 11 & 06.11 .90 & B & Hg211-84 & 4 & 01.04 .84 & $\mathrm{~N}$ \\
\hline Hg119-90 & 11 & 11.27 .90 & $\mathrm{C}$ & Hg212-84 & 9 & 05.21 .84 & $\mathrm{~F}$ \\
\hline Hg121-91 & 6 & 02.12 .91 & $\mathrm{C}$ & Hg213-85 & 4 & 02.01 .85 & $\mathrm{~F}$ \\
\hline Hg122-91 & 4 & 02.13 .91 & $\mathrm{E}$ & Hg214-85 & 4 & 03.11 .85 & $\mathrm{~F}$ \\
\hline Hg123-91 & 3 & 02.25 .91 & $\mathrm{C}$ & $\mathrm{Hg} 215-81$ (St) & $\mathrm{Y}$ & 8/?/81 & $\mathrm{N}$ \\
\hline Hg124-91 & 11 & 03.12 .91 & $\mathrm{C}$ & Hg216-81 & $\mathrm{X}$ & 12.27 .81 & $\mathrm{~N}$ \\
\hline Hg125-91 & 11 & 05.21 .91 & $\mathrm{C}$ & $\operatorname{Hg} 217-81(\mathrm{Ct})$ & $\mathrm{X}$ & 07.14 .81 & $\mathrm{~N}$ \\
\hline Hg126-91 & 4 & 06.13 .91 & $\mathrm{E}$ & Hg218-81 & $\mathrm{X}$ & 07.14 .81 & $\mathrm{~N}$ \\
\hline Hg127-91 & 13 & 06.24 .91 & $\mathrm{C}$ & Hg301-97 (Adult) & 14 & 02.18 .97 & B \\
\hline Hg128-92 & 9 & 03.10 .92 & $\mathrm{C}$ & Hg302-97 (Adult) & 14 & 12.02 .97 & $\mathrm{D}$ \\
\hline Hg129-92 & 12 & 09.15 .92 & B & Hg303-98 (Adult) & 14 & 03.16 .98 & $\mathrm{~A}$ \\
\hline Hg130-92 & 8 & 10.12.92 & $\mathrm{C}$ & Hg304-98 (Adult) & 14 & 03.24 .98 & $\mathrm{~A}$ \\
\hline Hg131-92 & 10 & 10.12 .92 & $\mathrm{C}$ & Hg306-98 (Adult) & 14 & 06.10 .98 & $\mathrm{~A}$ \\
\hline Hg132-92 & 11 & 10.15 .92 & B & Hg308-98 (Adult) & 14 & 06.23 .98 & B \\
\hline Hg135-92 & 1 & 12.02 .92 & $\mathrm{C}$ & Hg311-98 (Adult) & 14 & 09.29 .98 & B \\
\hline Hg136-92 & 11 & 12.02 .92 & $\mathrm{C}$ & Hg313-98 (Adult) & 14 & 11.19 .98 & B \\
\hline Hg138-93 & 9 & 03.16 .93 & B & Hg314-99 (Adult) & 14 & 09.22 .99 & B \\
\hline Hg139-93 & 1 & 10.27 .93 & $\mathrm{C}$ & Hg315-99 (Adult) & 14 & 11.04 .99 & $\mathrm{~A}$ \\
\hline Hg140-93 & 4 & 12.20 .93 & $\mathrm{C}$ & & & & \\
\hline
\end{tabular}

\section{MATERIALS AND METHODS}

Virus isolates. IHNV isolates from fish reared at privately owned rainbow trout farms were obtained from Doug Ramsey of Rangen Aquaculture, Hagerman, ID, and Scott LaPatra of Clear Springs Foods Inc., Buhl, ID. These isolates were originally obtained from dead or moribund rainbow trout with clinical IHN, except for 10 isolates that were obtained from asymptomatic adult fish as noted in Table 1. Virus isolates from fish reared at state hatchery facilities were obtained from Sharon Landin and Keith Johnson of the Eagle Fish Health Laboratory, Idaho Dept. of Fish \& Game, Eagle, ID, and the stock collections of the Western Fisheries Research Cen- ter, Seattle, WA. These isolates were obtained from several salmonid species (Table 1) and were taken from dead or moribund fish with clinical IHN or from asymptomatic adult fish surveyed at spawning. State and private facility isolates were obtained from either individual fish or several pooled fish within a single rearing unit, although specifics of this information were not available for many individual isolates. The majority of viruses were isolated as described by LaPatra (1994) and stored as frozen $\left(-75^{\circ} \mathrm{C}\right)$ aliquots of cell culture supernatant. Several pre-1986 isolates were stored lyophilized at room temperature. These isolates were re-hydrated with Eagle's minimum essential medium containing $10 \%$ fetal calf serum and other components as described in An- 
derson et al. (2000). Typically, the exact passage history of each isolate was not available, but the great majority were passaged only 1 to 3 times in cell culture. The 73 isolates sequenced in this study are labeled ' $\mathrm{Hg}$ ' for Hagerman Valley, followed by a 3 digit isolate number, and then the last 2 digits indicate the year of isolation (19XX).

Sequence analyses. A $303 \mathrm{nt}$ region (mid-G) of the IHNV glycoprotein (G) gene, from nt 686 to 988 (numbering as in GenBank accession no. U50401), was amplified and sequenced for 73 isolates. Cell culture supernatants containing virus were thawed on ice, diluted 1:20 in water, heated at $95^{\circ} \mathrm{C}$ for $2 \mathrm{~min}$ and cooled on ice. Reverse transcription-polymerase chain reaction (RTPCR) amplification was performed using $5 \mu \mathrm{l}$ of the heated 1:20 dilution in a $50 \mu \mathrm{l}$ reaction using 4.5 units avian myeloblastosis virus (AMV) reverse transcriptase (Promega) and 2.5 units Taq DNA polymerase (Promega) with $2.5 \mathrm{mM}$ magnesium chloride, $0.2 \mathrm{mM}$ dNTPs, and 7.5 units RNasin (Promega). Primers EXT-1 and EXT-2 (Table 2) were used in the initial RT-PCR at final concentrations of $1 \mu \mathrm{M}$. The reaction conditions included reverse transcription at $50^{\circ} \mathrm{C}$ for $60 \mathrm{~min}$ and denaturation at $95^{\circ} \mathrm{C}$ for $2 \mathrm{~min}$, followed by 25 to 30 cycles of $95^{\circ} \mathrm{C}$ for $30 \mathrm{~s}, 50^{\circ} \mathrm{C}$ for $30 \mathrm{~s}$, and $72^{\circ} \mathrm{C}$ for $60 \mathrm{~s}$, followed by a final extension at $72^{\circ} \mathrm{C}$ for $7 \mathrm{~min}$. The RT-PCR product was then used as a template for a $50 \mu$ nested PCR reaction with $2 \mu \mathrm{l}$ of the initial RT-PCR product and primers INT-1 and INT-2 (Table 2) under identical PCR reaction conditions and primer concentrations, without the initial $50^{\circ} \mathrm{C}$ reverse transcription step, reverse transcriptase, or RNasin. Resulting PCR products were purified with the StrataPrep PCR purification kit (Stratagene) and used as a template for synthesis of fluorescently labelled DNA with the BigDye terminator cycle sequencing kit (Applied Biosystems) according to manufacturer specifications using primers INT-1 and INT-2. The resulting labelled DNA was purified using Centri-Sep columns (Princeton Separations) and analyzed on an ABI-PRISM 310 genetic analyzer (Applied Biosystems).

Sequence files were edited and analyzed using Sequencher 4.1 (Gene Codes Corp.) and compared using AssemblyLIGN 1.0.9 (Oxford Molecular Group). Phylo-

Table 2. PCR primer positions and sequences

\begin{tabular}{lcll}
$\begin{array}{l}\text { Primer } \\
\text { name }\end{array}$ & $\begin{array}{c}\text { Nucleotide position } \\
\text { in the G gene }\end{array}$ & Orientation & Nucleotide sequence \\
\hline EXT-1 & $563-583$ & Sense & AGAGATCCCTACACCAGAGAC \\
EXT-2 & $1235-1255$ & Antisense & GGTGGTGTTGTCCGTGCAA \\
INT-1 & $623-643$ & Sense & TCACCCTGCCAGACTCATTGG \\
INT-2 & $1085-1105$ & Antisense & ATAGATGGAGCCTTGTGAT \\
a Nucleotide position relative to the G gene of IHNV strain RB (GenBank \\
accesssion U50401)
\end{tabular}

genetic analyses were performed with PAUP* 4.0 (Swofford 1998). The Sacramento River chinook virus (SRCV) isolate of IHNV was used as an outgroup for display of the tree as described in Troyer et al. (2000). The significance of the branching order was assessed by bootstrap resampling of 1000 replicates. Branches with values of $>70 \%$ correspond to a confidence interval of $>95 \%$ (Hillis \& Bull 1993). The cluster of sequences to the right of a branch with a significant bootstrap value constitute a 'clade.'

The nucleotide diversity $(\neq)$ within the IHNV population was calculated according to the method of Nei (1987) utilizing Kimura's 2-parameter model (Kimura 1980) as applied in the Arlequin 1.1 software package (Schneider et al. 1997). For evolutionary rate calculations the genetic distance of the sequence of each virus isolate from the inferred ancestor of the Hagerman Valley clade was calculated by summing the horizontal branch lengths of the neighbor-joining tree illustrated in Fig. 1. The genetic distance for each virus isolate was then plotted against the virus isolation dates. Linear regression of the data points produced a trendline, the slope of which is an estimate of the rate of evolution of the population expressed in mean number of mutations per nucleotide site per year. The significance of the positive slope of this line was assessed using InStat v. 3.01 (GraphPad Software). The number of nonsynonymous mutations per nonsynonymous site (dn) and the number of synonymous mutations per synonymous site (ds) were calculated using the method of Nei \& Gojobori (1986) with the Jukes-Cantor correction (Jukes \& Cantor 1969) as implemented in the MEGA 2.1 software package (Kumar et al. 2001).

\section{RESULTS}

\section{Mid-G sequences and phylogenetic analyses}

When the mid-G regions of 73 IHNV isolates were sequenced and compared, 41 unique sequence types were obtained. These sequence types were then compared by phylogenetic analyses to each other and to sequences of previously characterized IHNV isolates from the Hagerman Valley (Nichol et al. 1995, Troyer et al. 2000). Seven sequences representing IHNV isolated from outside the Hagerman Valley were also included for comparison. In the resulting phylogenetic tree the 73 isolates sequenced in this study are displayed in color (Fig. 1). All of the isolates from the Hagerman Valley formed a major cluster or clade which was separate from those 


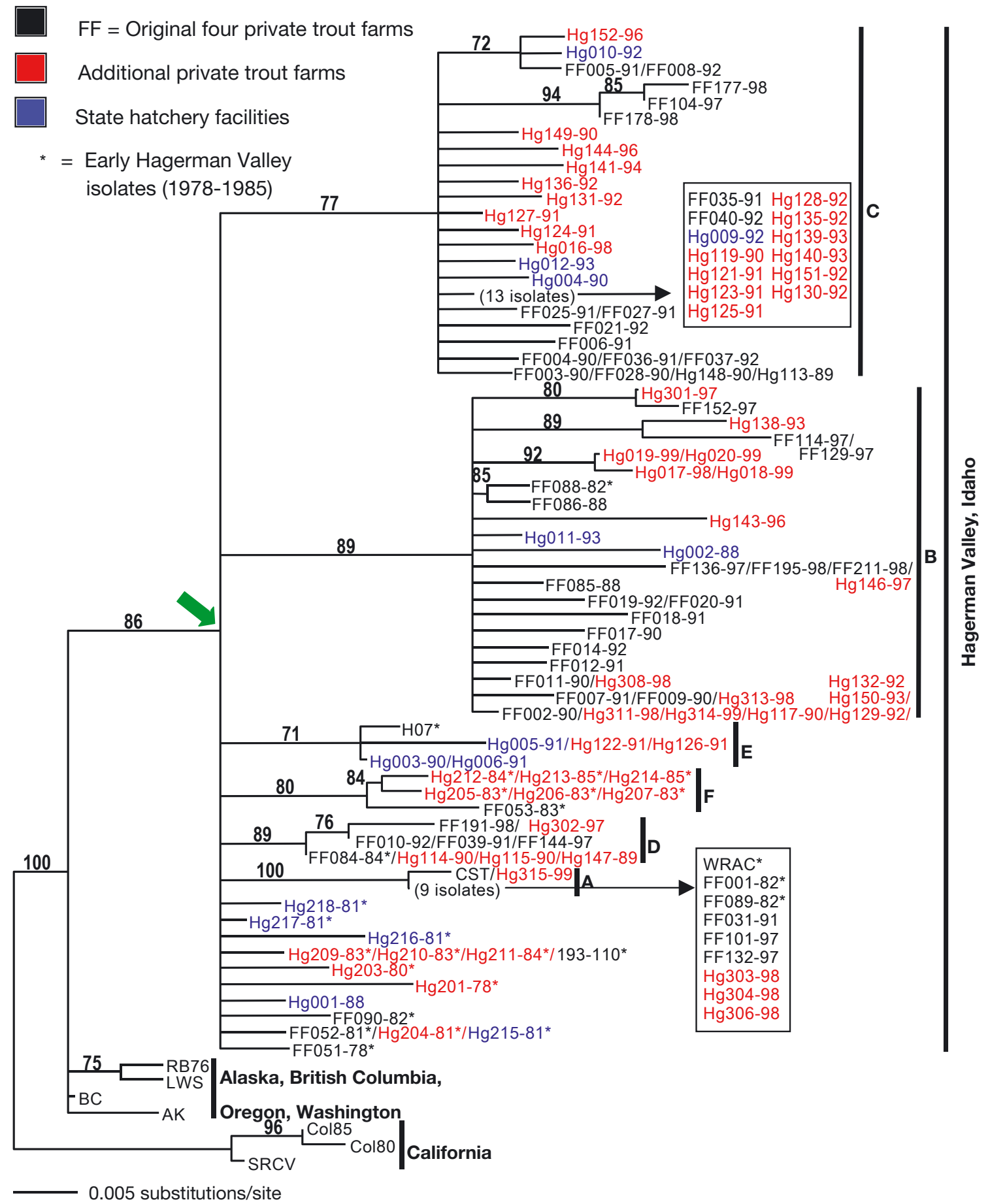

Fig. 1. Phylogenetic tree of IHNV isolates within the Hagerman Valley, ID, based on mid-G sequences (303 nt). The 73 isolates analyzed in this study are shown in color: blue for state hatchery facility isolates and red for private trout farm isolates. The 49 isolates from 4 private trout farms previously sequenced by Troyer et al. (2000) are shown in black, starting with an 'FF' designation. This neighbor-joining tree was generated with PAUP* (Swofford 1998) using SRCV as an outgroup for display of the tree. The significance of the branching order was assessed by bootstrap resampling of 1000 replicates. Branches with values of $>70 \%$ correspond to a confidence interval of $>95 \%$ (Hillis \& Bull 1993). Branches with values $<70 \%$ were collapsed. Sequences of isolates labeled H07, 193-110, CST, RB76, LWS, SRCV, Col80, and Col85 were from Nichol et al. (1995). BC: a major IHNV type found in British Columbia (Kurath et al. 2003). AK: a major IHNV type found in Alaska by Emmenegger et al. (2000). Maximum parsimony analysis of 1000 bootstrap resampled trees generated from the same sequence data produced a phylogeny with identical branching order at significant nodes and highly similar bootstrap values throughout (data not shown). Green arrow: ancestral node of the Hagerman Valley clade 
clades containing isolates from other geographic regions. This Hagerman Valley clade, referred to as the M clade (Kurath et al. 2003), is supported by a high confidence bootstrap value of 86 (Fig. 1). Within the Hagerman Valley clade, the majority $(70 \%)$ of the 73 isolates analyzed in this study were members of the previously described subclades A-D (Table 2). Two additional subclades, labeled E (5 isolates) and F (6 isolates), were also identified. Among the newly characterized isolates, 8 sequence types representing 11 isolates from before 1989 did not cluster into subclades A-F but instead fell on single branches linked directly to the ancestral node of the clade. These were referred to as ' $\mathrm{N}$ ' isolates, denoting their lack of subclade designation.

The isolates in this study were obtained from fish in 2 different environments: private rainbow trout farms and Idaho state hatcheries that culture anadromous salmon as well as rainbow trout. State and private facilities maintained similar virus types, with subclades B, C, and E present at both (Table 2). In 3 instances, isolates from state facilities had identical mid-G sequences to isolates from private facilities (note 3 branch tips of the tree in Fig. 1 which include both state and private facility isolates).

The majority of isolates in this study were obtained from fish at the fry and juvenile lifestages. However, 10 virus isolates from sexually mature adult rainbow trout at Facility 14 (Table 1) were also analyzed. The sequences of these isolates grouped with the A, B, and D subclades and were either identical or highly similar in sequence to virus isolates from other state hatchery and production farm facilities throughout the valley (Fig. 1). These isolates included the only subclade A virus found

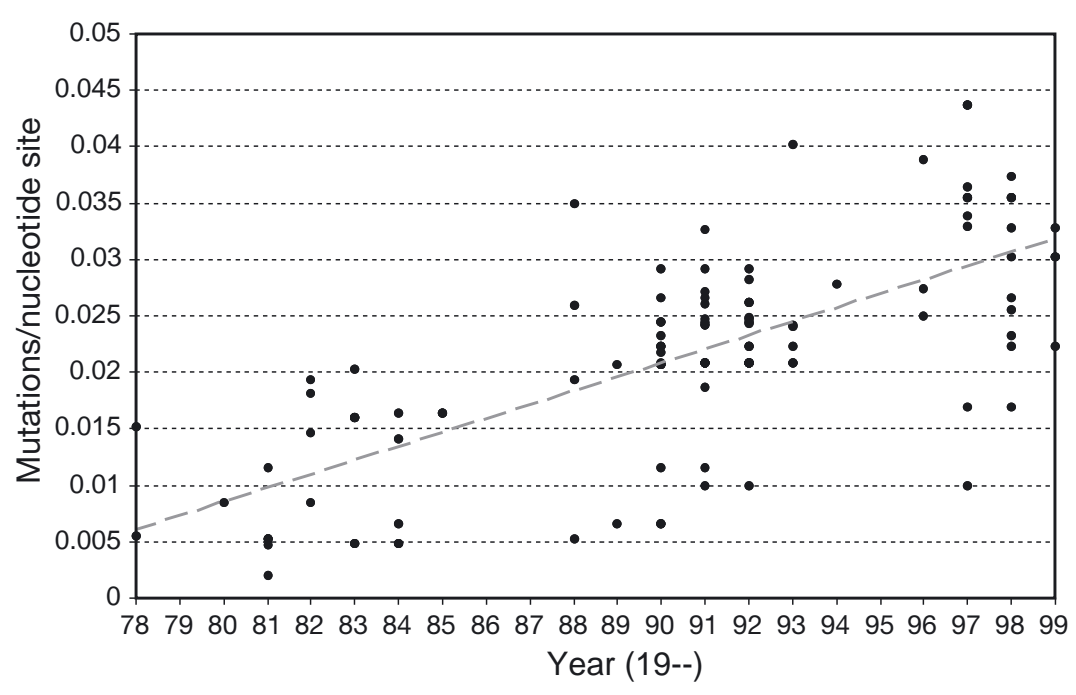

Fig. 2. Rate of evolution of IHNV in the Hagerman Valley. For each virus isolate the year of virus isolation was plotted against the genetic distance (number of mutations per nucleotide site) from the inferred ancestor of the Hagerman Valley clade in this study. However, Facility 14 is the only one in this study within the same production operation as the original 4 facilities, where subclade A was prevalent among fish from all lifestages (Troyer et al. 2000).

The intrapopulational nucleotide diversity parameter $\neq$ (Nei 1987) indicates the average number of nucleotide differences per nucleotide site between all pairs of sequences in a defined population, thus providing a measure of the overall genetic heterogeneity. In our previous study of IHNV at 4 trout farms, $\neq$ was 0.036 (Troyer et al. 2000). With the addition of the 73 isolates in this study, the $\neq$ of IHNV isolates from throughout the Hagerman Valley was 0.034 . This is 5 -fold higher than the nucleotide diversity for IHNV isolates from throughout Alaska ( $\neq=0.006$, Emmenegger et al. 2000) and coastal Washington ( $\neq=0.007$, Emmenegger \& Kurath, 2002).

In the phylogenetic analysis there was a trend toward greater divergence with time, i.e. older isolates in general tended to be positioned closer to the ancestral root of the Hagerman Valley clade, while newer isolates tended to be located toward the tips of the tree (Fig. 1). We estimated a rate of evolution for the mid-G sequence region of all characterized IHNV in the Hagerman Valley by plotting the genetic distance (number of mutations per nucleotide site) from the phylogenetically inferred ancestor of the Hagerman Valley clade (arrow in Fig. 1) versus the year of virus isolation for each isolate (Fig. 2). The rate observed was $1.2 \times 10^{-3}$ mutations per nucleotide site per year. While it may often be inappropriate to assume that RNA viruses evolve in a clock-like manner (reviewed in Domingo et al. 2001), this rate is in the middle of the range of evolutionary rates estimated for many other RNA viruses (Domingo et al. 2001, Jenkins et al. 2002). The positive slope in Fig. 2 is significantly different from zero $(\mathrm{p}<$ 0.0001 ) and serves to illustrate a general association between year of isolation and the number of mutations which have accumulated in each sequence $\left(r^{2}=0.50\right)$.

Alignment of all Hagerman Valley IHNV mid-G sequence types indicated that nucleotide substitutions were present throughout the mid-G region but that several hotspots for mutation existed (Fig. 3). Those nucleotide positions in which greater than one-third of the sequence types contained a mutation included positions 799, 800, 801, 812, 813, 855, 869, and 900 (Fig. 3). The presence of an excess of nonsynonmous mutations (those which result in a predicted amino-acid change) compared to the number of synonymous mutations (those which are silent) in a gene or region of a gene has been interpreted as 
evidence for positive selection acting on that region (Nei \& Gojobori 1986, Hughes \& Hughes 1995, Seibert et al. 1995). In order to examine the extent of positive selection acting on the mid-G region of IHNV in the Hagerman Valley, we compared the dn to the ds for all characterized IHNV in the Hagerman Valley. We found a dn/ds ratio of 0.43 , indicating an overall excess of synonymous mutation and thus a lack of evidence of positive selection. However, specific codons may in fact be under positive selection despite an overall excess of synonymous mutations for the entire region. Alignment of the amino acid sequences of all isolates in this study showed several hotspots for nonsynonymous mutation. In particular, glycoprotein amino acids 252, 256 and 270 each had an excess of nonsynonymous mutations.

\section{Geographic distribution of IHNV subclades}

The geographic distribution of IHNV subclades throughout the Hagerman Valley region of the midSnake River is shown diagrammatically in Fig. 4. This figure includes all 73 isolates analyzed in this study as well as the 84 isolates analyzed in Troyer et al. (2000). Individual facilities were found to maintain multiple subclades. In fact, at each site for which more than one isolate was analyzed, more than one subclade was found. Among the 21 facilities in Fig. 4, isolates representing the most prevalent subclades, B and C, were obtained from 13 and 16 different facilities, respectively, and thus were the most widely distributed (Fig. 4, Table 3). Subclade D was also found at 7 facilities throughout the valley (Fig. 4). The prevalences of subclades $B, C$, and D among the 17 facilities examined in this study were similar to those found in the original 4 trout farms (Table 3). Examination of virus from private farms and state hatcheries showed that both of these types of facilities harbor similar virus subclades (Fig. 4, Table 3). The complex distribution of subclades illustrated in Fig. 4 does not support a correlation between virus subclade and geographic location within the valley. Analysis of individual sequence types within subclades also does not support a correlation between virus genetic type and geographic location. For example, the most prevalent single sequence type identified in this study was found in 11 isolates at 8 different sites throughout the valley (data not shown).

\section{Temporal distribution of IHNV subclades}

The distribution of isolation dates from the 73 isolates examined in this study (Table 1) and the 84 isolates analyzed by Troyer et al. (2000) showed 2 clear

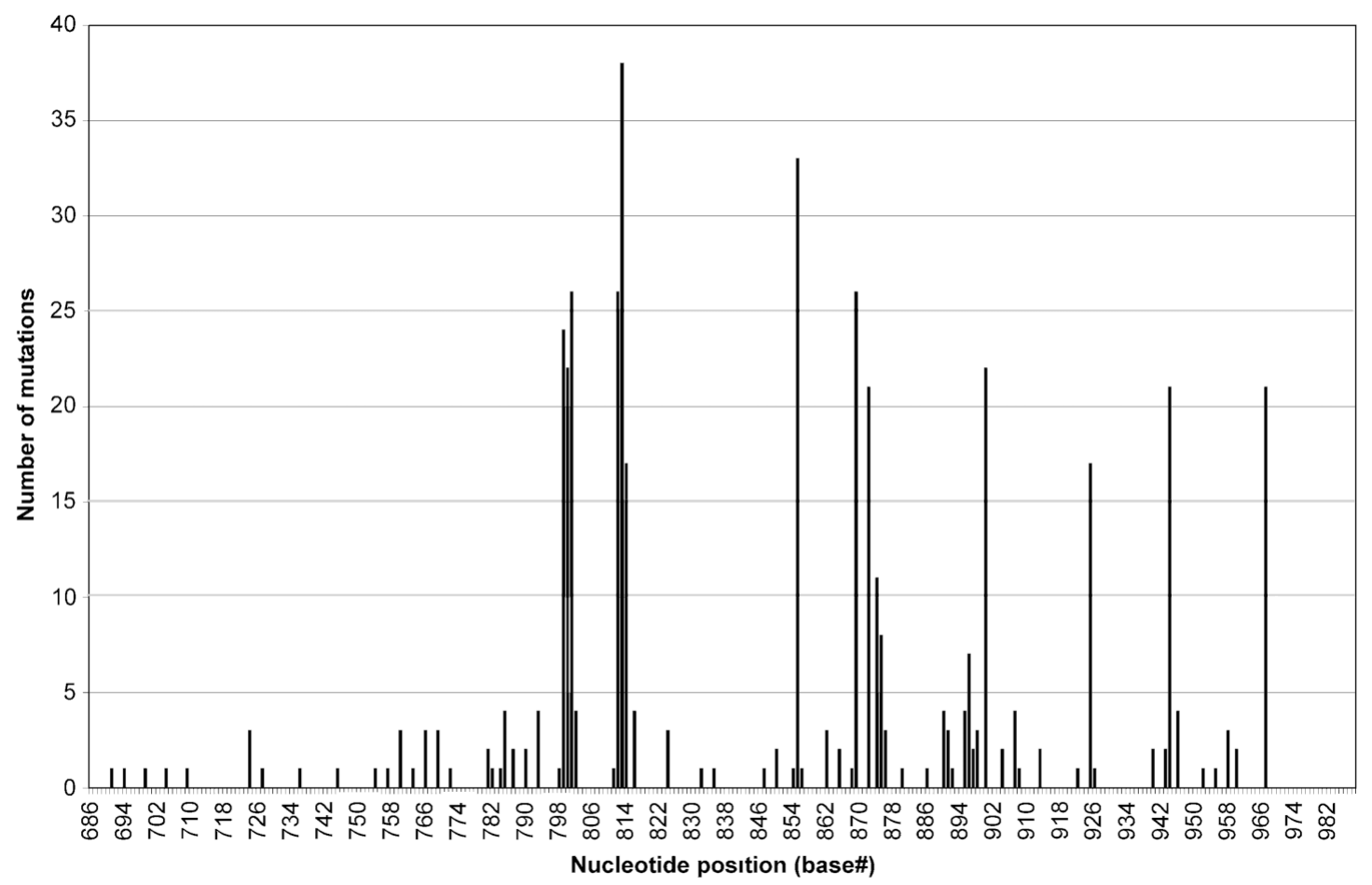

Fig. 3. Nucleotide mutation distribution among 64 Hagerman Valley sequence types. Sequences of all unique sequence types found among isolates from the Hagerman Valley in this study and the previous study (Troyer et al. 2000) were compared. The number of mutations compared to the dominant base at each position were plotted for positions 686-988 (numbering as in GenBank accession number U50401) of the G gene of IHNV 


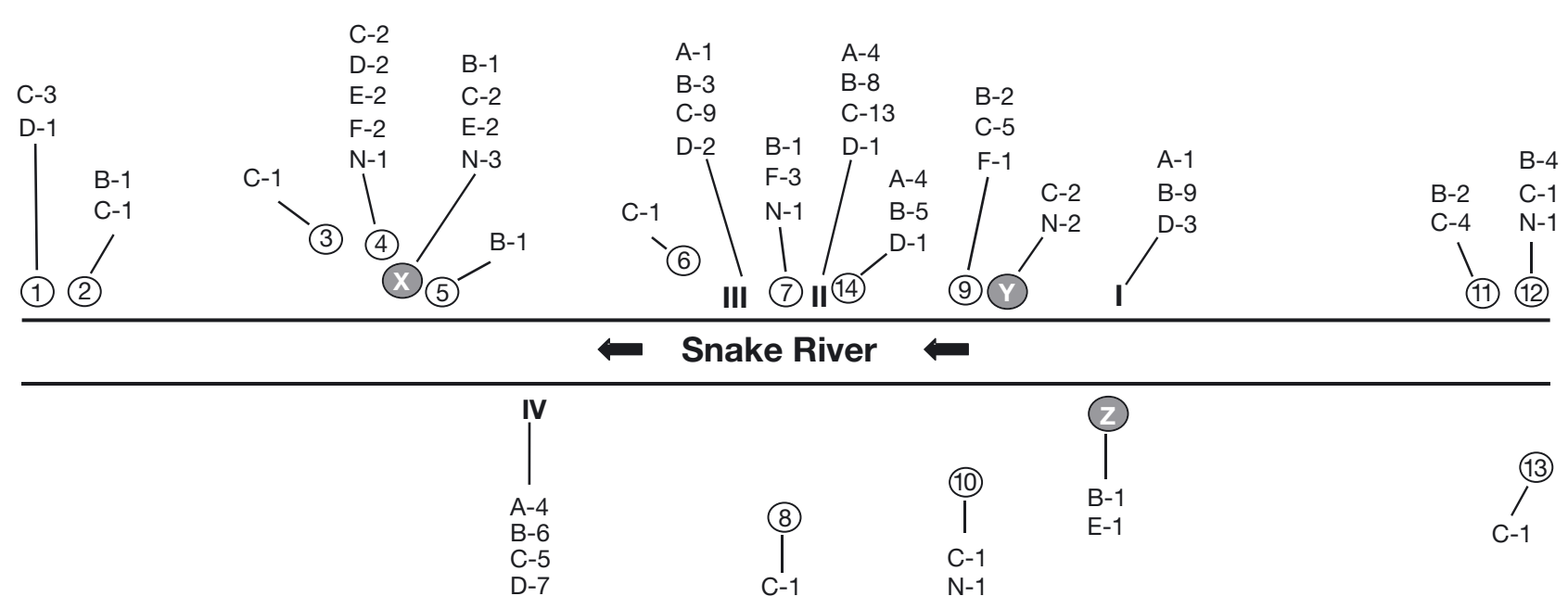

Fig. 4. Geographic distribution of IHNV subclades by facility. This diagram indicates the relative location of all facilities in this study along the Twin Falls to Hagerman reach of the Snake River, from river mile 610 to mile 569, for the purpose of simple epidemiological analyses. Distances are not precisely to scale and the Snake River is shown as straight and flowing from right to left for ease of illustration and interpretation. Numbers within circles indicate private trout farms (Facilities1-14). Roman numerals I-IV indicate the 4 private trout farms previously described (Troyer et al. 2000). X, Y, and Z: 3 Idaho state hatcheries. For each facility, the number of isolates classified into each phylogenetic subclade is shown, e.g. 'B-2' indicates 2 subclade B isolates

gaps in the data, with no isolates in 1986 to 1987 or in 1995. Therefore, we chose to divide the isolates into 3 temporal groups (1978 to 1985, 1988 to 1994, and 1996 to 1999) for the purpose of examining changes in the IHNV subclade distribution over time. Isolates from the early emergence period of the virus (1978 to 1985) are marked in Fig. 1 with an asterisk. The 2 earliest isolates analyzed, FF051-78 and Hg201-78, differed by 5 nucleotides $(1.7 \%)$. The 24 isolates taken during the early emergence of the virus within the valley included a number of variants represented by 16 different sequence types. Collectively, these sequences fit within the major Hagerman Valley clade of virus. However, nearly all (20/24) of these isolates either did not group with any subclade (listed as ' $\mathrm{N}$ ') or fell within the $\mathrm{F}$ subclade (Table 3). Only one (1/24) of the early isolates grouped with subclade $B$, and none grouped with subclade $C$, despite the fact that these 2 subclades represented the majority of the virus population present in the valley at later time points (Table 3). Lineage F was restricted to isolates from 3 facilities in 1983 to 1985 and thus it may have subsequently disappeared from the valley, possibly being outcompeted by other lineages. Similarly, lineage E was found at only 3 sites from 1990 to 1991 and may have subsequently disappeared from the valley.

Examination of the middle time period (1988 to 1994) showed that a general shift occurred from the previous period, with subclade $\mathrm{C}$ representing $53.7 \%$ of the isolates examined, subclade B representing $26.8 \%$, and

Table 3. IHNV subclade characteristics. No. of isolates: total number from the current data set of 73 isolates that group into each subclade. Numbers in parentheses represent previous data from the original 4 facilities examined in Troyer et al. (2000), and are included to facilitate comparison. No. of facilities: different facilities which were found to have isolates from each subclade. Numbers in parentheses refer to the original 4 facilities examined (Troyer et al. 2000). No. of isolates per time period: total number of isolates from each subclade observed during the given time periods; includes all 73 isolates from this study and all 84 isolates from the original 4 facilities (Troyer et al. 2000)

\begin{tabular}{|c|c|c|c|c|c|c|c|c|}
\hline \multirow{2}{*}{ Subclade } & \multirow{2}{*}{$\begin{array}{l}\text { No. of } \\
\text { isolates }\end{array}$} & \multirow{2}{*}{$\begin{array}{c}\text { No. of } \\
\text { facilities }\end{array}$} & \multirow{2}{*}{$\begin{array}{l}\text { Private } \\
\text { facility }\end{array}$} & \multirow{2}{*}{$\begin{array}{c}\text { State } \\
\text { facility }\end{array}$} & \multirow{2}{*}{$\begin{array}{c}\text { Mature } \\
\text { adult }\end{array}$} & \multicolumn{3}{|c|}{ No. of isolates per time period } \\
\hline & & & & & & 1978-1985 & $1988-1994$ & $1996-1999$ \\
\hline A & $4(11)$ & $1(4)$ & + & - & + & $2(8.3 \%)$ & $2(2.4 \%)$ & $11(21.6 \%)$ \\
\hline B & $18(27)$ & $9(4)$ & + & + & + & $1(4.2 \%)$ & $22(26.8 \%)$ & $22(43.1 \%)$ \\
\hline $\mathrm{C}$ & $25(28)$ & $13(3)$ & + & + & - & 0 & 44 (53.7\%) & $9(17.6 \%)$ \\
\hline $\mathrm{D}$ & $4(14)$ & $3(4)$ & + & - & + & $1(4.2 \%)$ & $8(9.8 \%)$ & $9(17.6 \%)$ \\
\hline E & $5(0)$ & $3(0)$ & + & + & - & 0 & $5(6.1 \%)$ & 0 \\
\hline F & $6(1)$ & $3(0)$ & + & - & - & $6(25.0 \%)$ & 0 & 0 \\
\hline $\mathrm{N}^{\mathrm{a}}$ & $11(3)$ & $6(0)$ & + & + & - & $14(58.3 \%)$ & $1(1.2 \%)$ & 0 \\
\hline Total & $73(84)$ & $17(4)$ & & & & 24 & 82 & 51 \\
\hline
\end{tabular}


subclades A, D, and E also present (Table 3). Comparison of the middle time period with the most recent period (1996 to 1999) demonstrated another shift, with subclade $\mathrm{C}$ declining in prevalence from $53.7 \%$ to $17.6 \%$, accompanied by increases in the prevalence of subclades A, B, and D (Table 3). This decline in the prevalence of subclade $\mathrm{C}$ was observed independently in both the original 84 isolates (Troyer et al. 2000) and the 73 isolates examined in this study (data not shown). Subclade B was the most prevalent in the most recent time period. The shifts observed indicated that the virus population in the Hagerman Valley changes with time.

\section{DISCUSSION}

The data presented here clearly establish that aquaculture facilities throughout the Hagerman Valley maintain multiple co-circulating lineages of IHNV. These lineages are shared among private trout farms and state hatchery facilities alike, regardless of rainbow trout life stage. Within the Hagerman Valley over a period of less than $30 \mathrm{yr}$, the virus has evolved to a greater level of diversity than that found among isolates from much larger regions of the virus' geographic range (Kurath et al. 2003). The presence of a general trend toward divergence over time suggests that the virus is actively evolving in the valley rather than exhibiting the relative genetic stasis observed in Alaska and the Washington state coastal region (Emmenegger et al. 2000, Emmenegger \& Kurath 2002).

The generation of this diversity may have been facilitated by conditions specific to Hagerman Valley aquaculture. Year-round trout production with the constant introduction of immunologically naïve fish may allow more rounds of viral replication per year than in anadromous hatchery or wild fish, where low-level chronic or carrier infection may be more common. In addition, partitioning of fish populations into numerous facilities, each with numerous rearing units may result in a lack of competition and purifying selection, allowing multiple variants to be simultaneously maintained. Rapid evolution of IHNV may also have been initiated by the process of virus adaptation to the unique Hagerman Valley environment which includes the rainbow trout host and constant $15^{\circ} \mathrm{C}$ water temperature. The finding of several hotspots for nonsynonymous mutation in the mid-G region suggests that host immune selection at several codons might also play a role in the generation of diversity, although the overall excess of synonymous mutations is evidence that immune selection is likely not the dominant selective force for this genomic region.
In addition to effects on virus evolution, the unique features of Hagerman Valley aquaculture might also influence virus population dynamics, e.g. the maintenance and spread of particular lineages, and thus contribute to increased genetic diversity. The presence of identical, or highly similar, virus types at different facilities throughout the valley indicates that virus traffic is very likely occurring between facilities within the valley at a rate which is sufficient to widely distribute the major virus lineages. The mechanism of this traffic is unknown. Some of this traffic may be due to the movement of fish between facilities owned by the same producer. However, this does not explain why state and private facilities or private facilities owned by different producers have the same virus types. At many facilities, spring-water is transported directly to the facility in enclosed pipes, so it is unlikely that water source is a mechanism of virus spread between facilities in these cases. However, in the case of facilities which receive water from unenclosed sources such as open channels, resident fish above the facility or other unknown hosts or vectors may play a role as sources of virus. In fact, indoor facilities for rearing eggs and very young fry have typically experienced high levels of IHN disease if fed by an open water source (G. Fornshell, University of Idaho Extension, pers. comm.). This is strong anecdotal evidence that IHNV is present in open water sources. However, most of the facilities analyzed in this study receive water from sources that are independent of each other, suggesting additional vectors. Birds have been implicated as a potential vector of fish pathogenic viruses (Peters \& Neukirch 1986, McAllister \& Owens 1992) and the application of bird-netting around facilities in the Hagerman Valley appears to have reduced the incidence of IHN disease in some facilities (D. Ramsey, Rangen Aquaculture, pers. comm.). Aerosols may also potentially serve to transfer fish pathogens (Wooster \& Bowser 1996), especially in the Hagerman Valley, which experiences strong winds and a significant amount of heavy mist which forms in the winter because the spring water is $15^{\circ} \mathrm{C}$ while air temperatures can commonly be $-4^{\circ} \mathrm{C}$ (SE LaPatra, Clear Springs Foods, pers. comm.). In general, personnel and equipment are not shared between fish producers, and farms practice strict hygiene for disease control. However, even rare or occasional events such as fish transfers or common use of equipment could serve to transfer IHNV.

It is particularly significant that private trout farm and state hatchery facilities have the same virus types, since these facilities have very different purposes and fish culture practices. Private trout farms engage in high intensity (fast growth rates and relatively high fish densities), year-round production of rainbow trout for human consumption, with fish 
being contained within the farm for their lifespan (approximately $1 \mathrm{yr}$ ). State resource mitigation hatcheries receive fish stocks (primarily rainbow trout and steelhead) as eggs or juveniles from a variety of sources around the state, raise the fish at facilities within the Hagerman Valley for limited periods and at relatively lower density, and then outplant these fish to regions around the state. Thus, fish raised within the Hagerman Valley might potentially serve as vectors of IHNV to other areas outside the Hagerman Valley as has been noted previously (Busch 1983). However, it is important to acknowledge that fish management personnel monitor fish health and consider the potential for the spread of pathogens when choosing to move fish from one location to another. It is also possible that trout farms could potentially spread virus outside of the valley in farm effluent, although approximately $99 \%$ of virus becomes inactivated in Snake River water within $24 \mathrm{~h}$ (LaPatra et al. 2001) and the concentrations of virus exiting facilities appear to be less than 7 plaqueforming units (pfu) $\mathrm{ml}^{-1}$ (SE LaPatra, Clear Springs Foods, pers. comm.). The relationship between genetic types of IHNV in Hagerman Valley aquaculture and genetic types of IHNV in fish throughout the Columbia River Basin, including the rest of Idaho, are discussed thoroughly by Garver et al. (2003, this issue).

It is not known whether the emergence of IHNV in the Hagerman Valley was the result of adaptation of the virus to the unique environment of the Hagerman Valley, an introduction of the virus from an exogenous source, or a change in the host or environment. Relative to the IHNV that was endemic in Alaskan sockeye salmon by 1974 (Amend \& Wood 1972, Grischkowsky \& Amend 1976), the emergence of IHNV in the Hagerman Valley would certainly have involved both adaptation to the rainbow trout host and to replication at the higher temperature of $15^{\circ} \mathrm{C}$ (Kurath et al. 2003). Interestingly, the 2 earliest isolates in this study (both 1978) had 5 nucleotide differences in the mid-G region. This suggests that either multiple related viruses were responsible for the early outbreaks or that very rapid evolution from a single progenitor occurred under new selection pressures. The early isolates of undefined subclade (classified as ' $\mathrm{N}$ ') may represent IHNV lineages that were not successfully maintained in the valley or were outcompeted by other lineages. Alternatively, some of these isolates may represent ancestors of the observed subclades A-F. Regardless of the early origin of IHNV in the Hagerman Valley, rainbow trout aquaculture appears to have allowed the virus to evolve multiple lineages which co-circulate in a complex manner throughout both state hatchery and trout farm facilities.
Acknowledgements. Virus isolates and information were graciously provided by Doug Ramsey, Rangen Aquaculture; Sharon Landin and Keith Johnson, Eagle Fish Health Lab, Idaho Department of Fish \& Game; and Scott LaPatra, Clear Springs Foods Inc. The authors also thank the trout producers of the Hagerman Valley for allowing these virus isolates to be shared and analyzed. Gary Fornshell of the University of Idaho, Twin Falls County Extension, provided invaluable information on Idaho aquaculture. Bill Batts provided excellent assistance with DNA sequencing. Thanks are extended to Jim Winton and Scott LaPatra for critical review of the manuscript and to Bob Busch for helpful discussion. This work was supported by the Western Fisheries Research Center, Biological Resources Division, US Geological Survey, through the Washington Cooperative Fish and Wildlife Research Unit. The Washington Cooperative Fish and Wildlife Research Unit is supported by the US Geological Survey, University of Washington, and the Washington Department of Ecology, Fish, and Wildlife, and Natural Resources.

\section{LITERATURE CITED}

Amend DF, Wood JW (1972) Survey for infectious hematopoietic necrosis (IHN) virus in Washington salmon. Prog Fish Cult 34:143-147

Anderson ED, Engelking HM, Emmenegger EJ, Kurath G (2000) Molecular epidemiology reveals emergence of a virulent IHN virus strain in wild salmon and transmission to hatchery fish. J Aquat Anim Health 12:85-99

Bootland LM, Leong JC (1999) Infectious hematopoietic necrosis virus. In: Woo PTK, Bruno DW (eds) Fish diseases and disorders, Vol 3. Viral, bacterial, and fungal infections. CAB International, New York, p 57-121

Brannon E, Klontz G (1989) The Idaho aquaculture industry. Northwest Environ J 5:23-35

Busch RA (1983) Viral disease considerations in the commercial trout industry in Idaho. In: Leong JC, Barila TY (eds) Proceedings of a workshop on viral diseases of salmonid fishes in the Columbia River Basin. Bonneville Power Administration Special Publication, Portland, OR, p 84-100

Domingo E, Biebricher CK, Eigen M, Holland JJ (2001) Quasispecies and RNA virus evolution: principles and consequences. Landes Bioscience, Georgetown, Tx

Emmenegger EJ, Kurath G (2002) Genetic characterization of infectious hematopoietic necrosis virus of Washington coastal salmonid stocks north of the Columbia River. J Aquat Anim Health 14:25-34

Emmenegger EJ, Meyers TR, Burton TO, Kurath G (2000) Genetic diversity and epidemiology of the infectious hematopoietic necrosis virus in Alaska. Dis Aquat Org 40:163-176

Garver KA, Troyer RM, Kurath G (2003) Two distinct phylogenetic clades of infectious hematopoietic necrosis virus overlap within the Columbia River basin. Dis Aquat Org 55:187-203

Grischkowsky RS, Amend DF (1976) Infectious hematopoietic necrosis virus prevalence in certain Alaskan sockeye salmon, Oncorhynchus nerka. J Fish Res Board Can 33: 186-188

Hillis DM, Bull JJ (1993) An empirical test of bootstrapping as a method for assessing confidence in phylogenetic analysis. Syst Biol 42:182-192

Hsu YL, Engelking HM, Leong JC (1986) Occurrence of different types of infectious hematopoietic necrosis virus in fish. Appl Environ Microbiol 52:1353-1361

Hughes MK, Hughes AL (1995) Natural selection on Plasmod- 
ium surface proteins. Mol Biochem Parasitol 71:99-113

Jenkins GM, Rambaut A, Pybus OG, Holmes EC (2002) Rates of molecular evolution in RNA viruses: a quantitative phylogenetic analysis. J Mol Evol 54:156-165

Jukes TH, Cantor CR (1969) Evolution of protein molecules. In: Munro HN (ed) Mammalian protein metabolism. Academic Press, New York, p 21-132

Kimura M (1980) A simple method for estimating evolutionary rate of base substitution through comparative studies of nucleotide sequences. J Mol Evol 16:111-120

Kumar S, Tamura K, Jakobsen IB, Nei M (2001) MEGA2: molecular evolutionary genetics analysis software. Bioinformatics 17:1244-1245

Kurath G, Garver KA, Troyer RM, Emmenegger EJ, EinerJensen K, Anderson ED (2003) Phylogeography of infectious hematopoietic necrosis virus in North America. J Gen Virol 84:803-814

LaPatra SE, Lauda KA, Morton AW (1991) Antigenic and virulence comparison of 8 isolates of infectious hematopoietic necrosis virus from the Hagerman Valley, Idaho, USA. In: Proceedings of the second international symposium on viruses of lower vertebrates. Oregon State University, Corvallis, OR, p 125-132

LaPatra SE, Lauda KA, Jones GR (1994) Antigenic variants of infectious hematopoietic necrosis virus and implications for vaccine development. Dis Aquat Org 20:119-126

LaPatra SE (1994) Infectious hematopoietic necrosis. In: Thoesen JC (ed) Suggested procedures for the detection and identification of certain finfish and shellfish pathogens, 4th edn, Vol. 1, Virology Chap. American Fisheries Society, Fish Health Section, Bethesda, MD, p V1-V5

LaPatra S, Troyer R, Shewmaker W, Jones G, Kurath G (2001) Understanding aquatic animal virus survival and trafficking and its role in risk assessment. In: Rodgers CJ (ed) Proceedings of the office international des epizooties (OIE) international conference on risk analysis in aquatic animal health. OIE, Paris, p 251-258

McAllister PE, Owens WJ (1992) Recovery of infectious pancreatic necrosis virus from the faeces of wild piscivorous birds. Aquaculture 106:227-232

Mulcahy D, Pascho R, Jenes CK (1984) Comparison of in vitro growth characteristics of 10 isolates of infectious haematopoietic necrosis virus. J Gen Virol 65:2199-2207

Nei M (1987) Molecular evolutionary genetics. Columbia University Press, New York

Nei M, Gojobori T (1986) Simple methods for estimating the number of synonymous and nonsynonymous nucleotide substitutions. Mol Biol Evol 3:418-426

Editorial responsibility: Jo-Ann Leong,

Kaneohe, Hawaii, USA
Nichol ST, Rowe JE, Winton JR (1995) Molecular epizootiology and evolution of the glycoprotein and non-virion protein genes of infectious hematopoietic necrosis virus, a fish rhabdovirus. Virus Res 38:159-173

Oshima KH, Arakawa CK, Higman KH, Landolt ML, Nichol ST, Winton JR (1995) The genetic diversity and epizootiology of infectious hematopoietic necrosis virus. Virus Res 35:123-141

Peters F, Neukirch M (1986) Transmission of some fish pathogenic viruses by the heron, Ardea cinerea. J Fish Dis 9: 539-544

Ristow SS, Arnzen de Avila J (1991) Monoclonal antibodies to the glycoprotein and nucleoprotein of infectious hematopoietic necrosis virus (IHNV) reveal differences among isolates of the virus by fluorescence, neutralization, and electrophoresis. Dis Aquat Org 11:105-115

Schneider S, Kueffer JM, Roessli D, Excoffier L (1997) Arlequin: a software for population genetic data analysis version 1.1. Departments of Anthropology and Ecology, University of Geneva, Geneva

Seibert SA, Howell CY, Hughes MK, Hughes AL (1995) Natural selection on the gag, pol and env genes of human immunodeficiency virus 1 (HIV-1). Mol Biol Evol 12: 803-813

Swofford DL (1998) PAUP* Phylogenetic Analysis Using Parsimony ( ${ }^{*}$ and other methods). Vers 4 . Sinauer Associates, Sunderland, MA

Troyer RM, LaPatra SE, Kurath G (2000) Genetic analyses reveal unusually high diversity of infectious haematopoietic necrosis virus in rainbow trout aquaculture. J Gen Virol 81:2823-2832

Walker PJ, Benmansour A, Calisher CH, Dietzgen R, and 7 others (2000) Family Rhabdoviridae. In: van Regenmortel MHV, Fauquet CM, Bishop DHL, Carstens EB and 7 others (eds). The 7 th report of the international committee for taxonomy of viruses. Academic Press, San Diego, CA, p 563-583

Winton JR, Arakawa CK, Lannan CN, Fryer JL (1988) Neutralizing monoclonal antibodies recognize antigenic variants among isolates of infectious hematopoietic necrosis virus. Dis Aquat Org 4:199-204

Wolf K (1988) Fish viruses and fish viral diseases. Cornell University Press, Ithaca, NY

Wooster GA, Bowser PR (1996) The aerobiological pathway of a fish pathogen: survival and dissemination of Aeromonas salmonicida in aerosols and its implications in fish health management. J World Aquacult Soc $27: 7-14$

Submitted: August 8, 2002; Accepted: April 11, 2003

Proofs received from author(s): July 11, 2003 